\title{
ANALISIS WEBSITE E-LEARNING BERBASIS STANDAR SCORM CONTENT AGGREGATION MODEL 2.1 DI FAKULTAS ILMU KOMPUTER UNIVERSITAS BANDAR LAMPUNG
}

\author{
Wiwin Susanty \\ Putri Oriniati \\ Program Studi Sistem Informasi \\ Fakultas Ilmu Komputer \\ Universitas Bandar Lampung \\ Telp. (0721) 701463, (0721)701979 \\ Email.putrioriniati@ymail.com
}

\begin{abstract}
Universitas Bandar Lampung adalah Perguruan Tinggi Swasta terbesar di Provinsi Lampung yang berdiri sejak tahun 1984 di bawah naungan Yayasan Administrasi Lampung (YAL) yang bergerak dalam bidang pendidikan. Tujuan dari penulisan ilmiah ini adalah untuk menganalisis website e-Learning Berbasis standar SCORM Content Aggregation Model (CAM) di Fakultas Ilmu Komputer Universitas Bandar lampung agar dapat membantu dalam proses kegiatan belajar mengajar (KBM). Dengan adanya penelitian ini, diharapkan dapat membantu masalah yang dihadapi FIK. Seperti kurangnya format-format materi dan konten-konten pembelajaran yang belum terstruktur didalam website e-Learning. Hasil dari penelitian ini adalah sebuah website e-Learning yang berbasis Standar SCORM Content Aggregation Model $(C A M)$.
\end{abstract}

Keywords : e-Learning, SCORM Content Aggregation Model (CAM)

\section{PENDAHULUAN}

\subsection{Latar Belakang}

Seiring dengan perkembangan Teknologi Informasi yang semakin pesat, kebutuhan akan suatu konsep dan mekanisme belajar mengajar berbasis TI menjadi tidak terelakkan lagi. Konsep yang dikenal dengan sebutan $e$ Learning ini membawa pengaruh terjadinya proses transformasi pendidikan konvensional ke bentuk digital, baik secara isi dan sistemnya. Saat ini konsep $e$ Learning sudah banyak diterima oleh masyarakat dunia, terbukti dengan maraknya implementasi e-Learning di lembaga pendidikan maupun industri (Wahono, 2005). Beberapa perguruan tinggi menyelenggarakan kegiatan pembelajaran elektronik sebagai suplemen (tambahan) terhadap materi pelajaran yang disajikan secara reguler di kelas (Wildavsky, 2001; Lewis, 2002). Sebagai salah satu perguruan tinggi di Lampung, Universitas Bandar Lampung khususnya Fakultas Ilmu Komputer berperan dalam pengembangan Tekhnologi Informasi (TI). Selama ini proses pembelajaran di Fakultas Ilmu Komputer masih bersifat konvensional, Sistem $e$ Learning yang sudah ada belum sepenuhnya berjalan, banyak format-format materi dan konten-konten didalam website e-Learning FIK UBL yang belum terstuktur.

SCORM (Sharable Content Object Reference Model) adalah sebuah standar e-Learning yang dikembangkan oleh ADL (Advanced Distributed Learning). Sebagai standar pendistribusian paket $e$ Learning yang dapat digunakan untuk menampung berbagai spesifikasi dan standar untuk konten $e$ Learning berbasis web dengan mengacu pada interoperability, accesibility, dan reusability (Rice 2006). SCORM memiliki tiga topik standarisasi utama yaitu Content Aggregation Model (CAM), Run-Time Environment (RTE), dan Sequencing and Navigation (SN). SCORM CAM mengatur standar identifikasi, resources agregation dan packaging pada learning content yang terstruktur. SCORM RTE mengatur tentang launching, komunikasi antar e-Learning dan tracking content dalam lingkungan berbasis web. SCORM SN mengatur tentang pengurutan dan navigasi yang mempengaruhi bagaimana content dibangun pada manifest.

Tujuan dari SCORM adalah sebuah upaya untuk mulai menyeragamkan pengembangan sistem $e$ Learning berbasiskan teknologi web yang disebut Learning Management Systems (LMS). SCORM menggunakan pendekatan object oriented dan 
memandang bahwa setiap learning object atau content object sebagai sekumpulan objek yang dapat disatukan untuk membangun suatu sistem yang lebih besar.

Website e-learning di Fakultas Ilmu Komputer Universitas Bandar Lampung, perlu menerapkan standar SCORM khususnya SCORM CAM (Content Aggregation Model) yang digunakan untuk membuat aturan pedagogi untuk desainer format materi pembelajaran dengan konten-konten yang terstruktur.

\subsection{Identifikasi Masalah}

Dari analisis yang dilakukan terdapat beberapa hal yang menjadi masalah yaitu:

1. Kurangnya konten-konten dan elemen-elemen didalam website $e$-Learning.

2. Kurangnya desain materi pembelajaran dalam website e-Learning yang mengakibatkan kurangnya minat mahasiswa/i untuk menggunakannya.

3. Belum pernah dilakukan pengukuran kualitas pembelajaran dengan standar SCORM CAM dalam website $e$-Learning.

\subsection{Rumusan Masalah}

Melihat latar belakang diatas maka dapat dirumuskan beberapa pertanyaan yaitu:

1. Apakah sistem e-Learning di Fakultas Ilmu Komputer Universitas Bandar Lampung ini sudah memenuhi standar SCORM khususnya SCORM dengan Content Aggregation Model?

2. Bagaimana menerapkan standar SCORM di Fakultas Ilmu Komputer Universitas Bandar Lampung sehingga mampu mendukung kegiatan belajar mengajar?

\subsection{Batasan Masalah}

Penelitian yang dilakukan membahas standar yang berhubungan dengan standar e-Learning yaitu standar SCORM Content Aggregation Model dengan kategori umum dan kategori pendidikan. Lingkup pembahasan dalam penelitian dilakukan pada website e-Learning Fakultas Ilmu Komputer Universitas Bandar Lampung.

\subsection{Manfaat Penelitian}

Penelitian ini diharapkan dapat bermanfaat :

1. Manfaat Praktis Penelitian ini diharapkan dapat digunakan sebagai tolak ukur tingkatan standar pembelajaran sesuai dengan standar SCORM.
2. Manfaat Teoritis dari Penelitian ini adalah diharapkan Penelitian ini dapat menghasilkan suatu metode pengukuran baru.

\subsection{Kerangka Pemikiran}

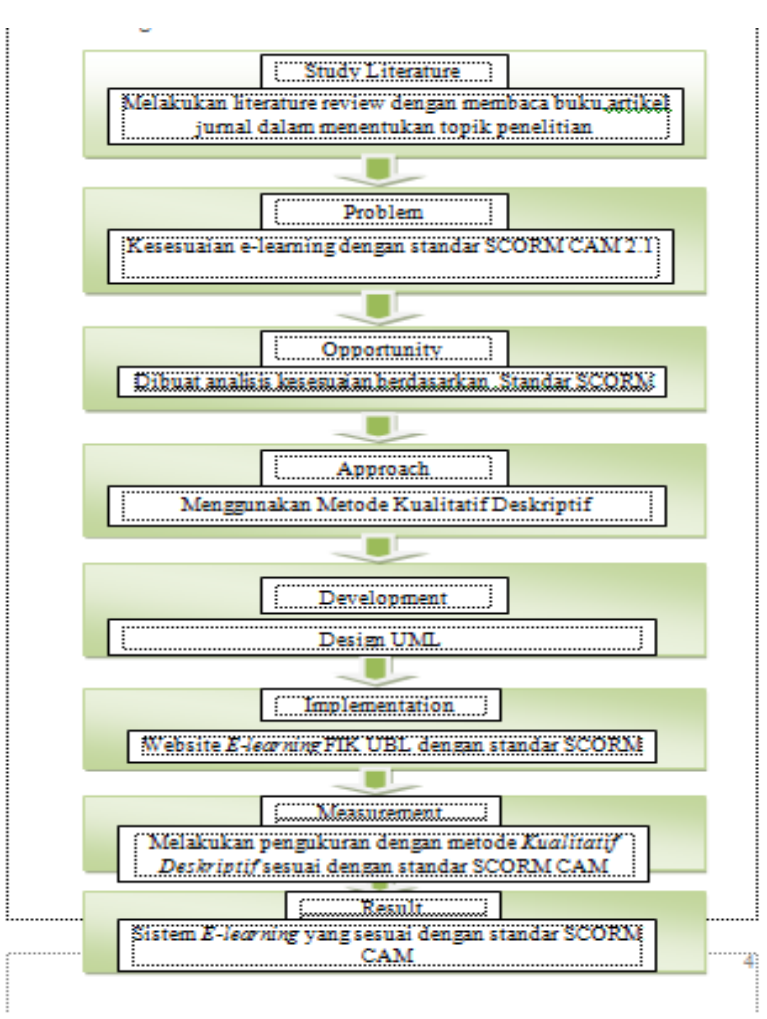

Gambar 1. Kerangka Pemikiran

Dari gambar diatas maka dapat disimpulkan penjelasan :

1. Study literature : Melakukan literature review dengan membaca buku, jurnal, artikel guna untuk menentukan topik pemilihan.

2. Problem : Kesesuaian sistem e-Learning dengan standar SCORM

3. Oportunity : Dibuat analisis kesesuaian berdasarkan dengan standar SCORM CAM 2.1

4. Approach : Menggunakan metode kualitatif deskriptif

5. Development : Design UML

6. Implementation : Website e-Learning FIK UBL dengan standar SCORM

7. Measurement : Melakukan pengukuran dengan Metode Kualitatif Deskriptif sesuai dengan standar SCORM CAM 2.1

8. Result : Sistem e-Learning yang sesuai dengan standar SCORM CAM 2.1 


\section{LANDASAN TEORI}

\subsection{SCORM (Sharable Content Object Reference Model)}

SCORM (Shareable Content Object Reference Model) adalah standar pendistribusian paket $e$-Learning yang dapat digunakan untuk menampung berbagai spesifikasi dan standar untuk konten e-Learning berbasis web dengan mengacu pada interoperability, accesibility, dan reusability Rice (2006). Tujuan dari SCORM adalah sebuah upaya untuk mulai menyeragamkan pengembangan sistem e-Learning berbasiskan teknologi web yang disebut Learning Management Systems (LMS). SCORM menggunakan pendekatan object oriented dan memandang bahwa setiap learning object atau content object sebagai sekumpulan objek yang dapat disatukan untuk membangun suatu sistem yang lebih besar.Metadata dalam SCORM merupakan identitas untuk setiap sumber belajar, dan memudahkan untuk mengidentifikasi isi, kategori, dan pencarian Wang (2007). Selain itu, dangan menggunakan metadata yang tepat, tujuan dari sharing dan reuse dapat terfasilitasi. Content packaging menyediakan standarisasi cara belajar untuk bertukar konten antara sistem atau perangkat yang berbeda, seperti LMS dan content authoring tool.

Standar SCORM dibangun oleh Advanced Distributed Learning Network (ADLNet) dengan komponen-komponen yang diperoleh dari berbagai kontributor. SCORM terdiri dari tiga elemen penting, yakni :

1. SCORM mengimplementasikan "Learning Object Meta-data" (LOM) yang didasarkan pada spesifikasi milik IMS dan ARIADNE. Pada Juli 2003 LOM diterima sebagai standar IEEE dan menerangkan mengenai konten (judul, deskripsi, keyword), pemilik, harga, technical requirement, dan tujuan educational suatu konten.

2. Proses pemaketan dan transmisi konten learning pada SCORM yang dirancang oleh IMS.

3. Setiap konten SCORM harus memuat suatu file dalam XML yang mendaftar semua file resource yang digunakan dan relasi / struktur antara file-file tersebut. Resource pada SCORM disebut SCO (Sharable Content Object) yang biasanya disimpan sebagai file bertipe zip. File zip ini dapat disimpan dengan mudah, dishare, atau diimpor ke software SCORM yang kompatibel, biasa berupa Learning Management System (LMS). Elemen ketiga dari SCORM adalah mekanisme komunikasi antara SCO dan LMS. The Application Program Interface
(API) yang memungkinkan interaksi antara SCO dan LMS dibangun oleh Aircraft Industry Computer Committee (AICC).

Standarisasi diperlukan untuk menjamin akuntabilitas konten pembelajaran yang digunakan pada e-Learning. Berdasarkan pengamatan dilapangan, banyak penyedia konten e-Learning tidak memperhatikan standarisasi pendistribusian konten eLearning. Model pembelajaran e-Learning harus memenuhi standarisasi sebagai berikut :

1. Accessibility, kemampuan untuk mencari dan mengakses komponen instruksional dari suatu lokasi dan mengirimkannya ke banyak lokasi lain.

2. Adaptability,kemampuan untuk menyesuai kan materi sesuai dengan kebutuhan pribadi dan organisasi.

3. Affordability,kemampuan untuk meningkat kan efisiensi dan produktifitas dengan mengurangi biaya dan waktu yang dibutuhkan dalam pengiriman materi.

4. Durability, kemampuan bertahan dari perkembangan dan perubahan teknologi tanpa banyak mengeluarkan biaya untuk mendesain, mengkonfigurasi serta penyimpanan ulang.

5. Interoperability, kemampuan untuk mengambil komponen-komponen materi yang dikembangkan di suatu lokasi dengan kelengkapan tool atau platformnya dan menggunakannya di tempat lain dengan tool atau platform yang berbeda.

6. Reusability, kemudahan menggabungkan dan menggunakan kembali komponen-komponen materi dalam aplikasi-aplikasi dan kontekskonteks bertingkat. Mackenzie (2004).

\subsection{Content Aggregation Model (CAM)}

Content Aggregation Model dapat digunakan untuk membuat aturan pedagogi untuk desainer materi pembelajaran. Pedagogi adalah sebuah ilmu yang mempelajari mengenai cara pembuatan materi pembelajaran. Content Aggregation Model memiliki beberapa komponen penting, diantaranya Assets, Sharable Content Object (SCO) dan Content Aggregation. Sebuah materi pembelajaran juga terdiri dari beberapa asset, diantaranya semua media teks, gambar, suara, halaman web, tugas, quiz atau data apapun yang dapat ditampilkan melalui browser. Sebuah asset memiliki keterangan mengenai dirinya sendiri dengan menggunakan Asset Metadata. 
1. Asset

Asset adalah blok bangunan yang utama dari sebuah learning resource. Asset merupakan representasi elektronik dari media seperti, teks, gambar,suara, obyek penelitian atau bagian data lain yang dapat diolah oleh web client dan ditampilkan ke siswa.

\section{Sharable Content Object (SCO)}

Mewakili sekumpulan dari asset dimana didalamnya terdapat sebuah asset yang dapat dilaunch pertama kali dengan memanfaatkan SCORM Run Time Environtment untuk melakukan komunikasi dengan Learning Management System $(L M S)$. SCO adalah bagian terkecil dari sebuah materi pembelajaran yang dapat di-tracking oleh LMS dengan SCORM Run Time Environtment.

\section{Content Aggregation}

Content Aggregation adalah sebuah peta (struktur materi) yang dapat digunakan untuk menggabungkan berbagai bahan pembelajaran SCO menjadi satu modul pembelajaran yang utuh. Content Aggregation juga mendefinisikan struktur materi yang digunakan sebagai mekanisme untuk menentukan urutan sebuah materi pembelajaran yang akan ditampilkan kepada mahasiswa. Content Aggregation mengandung dua bagian penting, yaitu manifest dan metadata. Manifest memberikan informasi mengenai daftar file yang terdapat dalam suatu content package, sedangkan metadata memberikan keterangan metadata terhadap content package tersebut. Content Aggregation ini diimplementasikan dalam file imsmanifest.xml yang harus ada dalam setiap SCORM Content Package. Gambar berikut menunjukkan Content Aggregation Hierarchy.

\subsection{Moodle}

Moodle merupakan singkatan dari Modular ObjectOriented Dynamic Learning Environment yang berarti tempat belajar dinamis dengan menggunakan model berorientasi objek. Dalam penyediannya MOODLE memberikan paket software yang lengkap (MOODLE + Apache + MySQL + PHP).

a. Apache adalah sebuah nama web server yang bertanggung jawab pada request-response HTTP dan logging informasi secara detail (kegunaan basic nya).

b. MySQL adalah perangkat lunak database server atau sebut saja Database Smart. Database ini semakin lama semakin populer. Dengan menggunakan database ini, data semakin aman dan berdaya guna. Database ini juga banyak dipakai pada web database sehingga data semakin terintegrasi antara database dekstop dengan database web. Untuk menggunakan database MySQL harus menginstalasinya dahulu ke komputer.

c. PHP adalah sekumpulan script yang digunakan untuk mengolah data form dari web (Rasmus Lerdorf pada tahun 1995).

\subsection{Pengertian e-Learning}

Istilah e-Learning mengandung banyak pengertian yang sangat luas,sehingga banyak pakar yang menguraikan tentang definisi e-Learning dari berbagai sudut pandang. Beberapa definisi yang cukup diterima diberbagai banyak pihak adalah :

1. e-Learning adalah semua kegiatan pendidikan yang menggunakan media komputer dan internet. Effendi dan Zhuang (2005:6)

2. e-Learning adalah penggunaan web dan tekhnologi internet untuk menciptakan pengalaman yang mendidik antara sesama manusia.

Horton Shackelford ( 2005:7)

3 e-Learning adalah penggunaan tekhnologi komputer atau elektronik device lainnya untuk mendukung proses pembelajaran.

Rosenberg ( 2006:3)

\section{METODELOGI PENELITIAN}

Metode Penelitian adalah cara ilmiah untuk mendapatkan data dengan tujuan dan kegunaan tertentu. Metode penelitian yang digunakan dalam penelitian ini adalah metode deskriptif kualitatif. Metode deskriptif kualitatif adalah penggambaran secara kualitatif fakta, data atau objek material yang bukan berupa rangkaian angka, melainkan berupa ungkapan bahasa atau wacana (apapun itu bentuknya) melalui interpretasi yang tepat dan sistematis (Wibowo, 2011: 43).

Metode penelitian kualitatif adalah metode untuk menyelidiki obyek yang tidak dapat diukur dengan angka-angka ataupun ukuran lain yang bersifat eksak. Penelitian kualitatif juga bisa diartikan sebagai riset yang bersifat deskriptif dan cenderung menggunakan analisis dengan pendekatan induktif.

\subsection{Metode Pengumpulan Data}

Metode pengumpulan Data yang digunakan pada Penelitian ini, yaitu :

\section{Observasi}


Observasi adalah kemampuan seseorang untuk menggunakan pengamatannya melalui hasil kerja pancaindra mata serta dibantu dengan pancaindra lainnya. Menurut Patton (dalam Poerwandari 1998) tujuan observasi adalah mendeskripsikan setting yang dipelajari, aktivitas-aktivitas yang berlangsung, orang-orang yang terlibat dalam aktivitas, dan makna kejadian di lihat dari perpektif mereka yang terlihat dalam kejadian yang diamati tersebut.

Dalam penelitian ini penulis melakukan observasi pada website e-Learning FIK UBL selama penelitian ini berlangsung. Guna menganalisa website e-Learning tersebut berdasarkan kategorikategori pada standar SCORM CAM.

\subsection{Variabel Penelitian}

Variabel penelitian yang digunakan dalam penelitian ini terhadap website e-Learning dengan menggunakan standar SCORM CAM yang terdiri dari kategori-kategori dalam tabel sebagai berikut :

\begin{tabular}{|l|l|l|}
\hline \multicolumn{2}{|c|}{ SCORM Meta-data Informasi Model } \\
\hline Nr & \multicolumn{1}{|c|}{ Nama } & \multicolumn{1}{c|}{ Penjelasan } \\
\hline 1 & Kategori Umum & $\begin{array}{l}\text { Kelompok kategori ini menggambarkan sumber } \\
\text { daya informasi umum secara keseluruhan }\end{array}$ \\
\hline 1.1 & Identifier & $\begin{array}{l}\text { Elemen data ini untuk menggambarkan label } \\
\text { global yang unik untuk mengidentifikasi } \\
\text { sumber belajar.Elemen data ini tidak akan } \\
\text { digunakan, karena tidak ditentukan metode } \\
\text { untuk pembentukan identifier global yang unik. }\end{array}$ \\
\hline 1.2 & Judul & $\begin{array}{l}\text { Elemen data ini menggambarkan nama yang } \\
\text { diberikan untuk sumber belajar. }\end{array}$ \\
\hline 1.4 & Katalog Entri & $\begin{array}{l}\text { Elemen ini menggambarkan data entri dalam } \\
\text { katalog (yaitu sebuah daftar identifikasi sistem) } \\
\text { yang ditugaskan untuk sumber belajar. } \\
\text { Kategori sub-harus menjelaskan sumber belajar } \\
\text { menurut beberapa sistem katalogisasi dikenal } \\
\text { sehingga memungkinkan mencari secara } \\
\text { ekstemal yang terletak sesuai dengan } \\
\text { metodologi sistem tertentu. }\end{array}$ \\
\hline Bahasa & $\begin{array}{l}\text { Elemen data ini menggambarkan bahasa } \\
\text { manusia utama atau bahasa yang digunakan } \\
\text { dalam hal sumber belajar untuk berkomunikasi }\end{array}$ \\
\hline
\end{tabular}

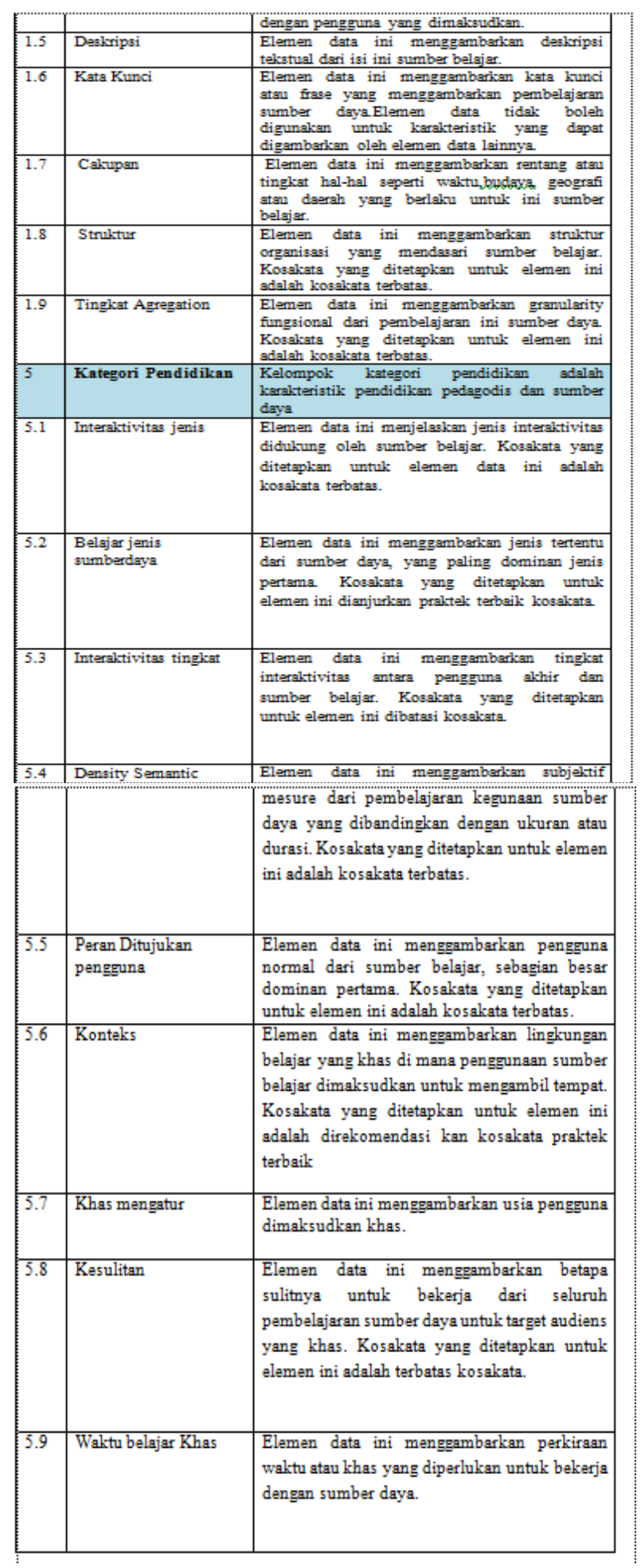

1.

Mahasiswa/I melakukan login terlebih dahulu, jika mahasiswa belum terdaftar di e-Learning FIK 
UBL mahasiswa/I dapat melakukan pendaftaran di e-Learning FIK UBL, lalu mahasiswa/I dapat melakukan perubahan pada profil, dapat melihat dan mencari kategori kursus serta mengikuti kategori kursus tersebut. mahasiswa/I dapat mendownload materi dan keluar.

\section{PEMBAHASAN}

E-learning merupakan cara baru dalam proses belajar mengajar yang menggunakan media elektronik khususnya internet sebagai sistem pembelajarannya. $E$ learning merupakan dasar dan konsekuensi logis dari perkembangan teknologi informasi dan komunikasi. Dari hasil proses-proses dalam kategori standar SCORM CAM di jabarkan dalam tabel berikut ini berdasarkan tingkat kesesuaian dengan standar SCORM 1.2 :

SCORM Meta-data Informasi Model

(Tabel 4.1) Kategori Scorm CAM berdasarkan lesesuaian e-Learning FIK UBL

\begin{tabular}{|c|c|c|c|}
\hline $\mathrm{Nr}$ & Nama & Penjelasan & Ket \\
\hline 1 & Kategori Umum & $\begin{array}{l}\text { Kelompok kategori ini menggambarkan } \\
\text { sumber daya informasi umum secara } \\
\text { keseluruhan }\end{array}$ & \\
\hline 1.1 & Identifier & $\begin{array}{l}\text { Elemen data ini untuk menggambarkan } \\
\text { label global yang unik untuk } \\
\text { mengidentifikasi sumber belajar. }\end{array}$ & $\checkmark$ \\
\hline 1.2 & Judul & $\begin{array}{l}\text { Elemen data ini menggambarkan nama } \\
\text { yang diberikan untuk sumber belajar. }\end{array}$ & $\checkmark$ \\
\hline 1.3 & Katalog Entri & $\begin{array}{l}\text { Elemen ini menggambarkan data entri } \\
\text { dalam katalog (yaitu sebuah daftar } \\
\text { identifikasi sistem) yang ditugaskan } \\
\text { untuk sumber belajar. Kategori sub- } \\
\text { harus menjelaskan sumber belajar } \\
\text { menurut beberapa sistem katalogisasi } \\
\text { dikenal sehingga memungkinkan } \\
\text { mencari secara eksternal yang terletalk } \\
\text { sesuai dengan metodologi sistem } \\
\text { tertentu. }\end{array}$ & $\checkmark$ \\
\hline 1.4 & Bahasa & $\begin{array}{l}\text { Elemen data ini menggambarkan bahasa } \\
\text { manusia utama atau bahasa yang } \\
\text { digunakan dalam hal sumber belajar } \\
\text { untuk berkomunikasi dengan pengguna } \\
\text { yang dimaksudkan. }\end{array}$ & $\checkmark$ \\
\hline 1.5 & Deskripsi & $\begin{array}{l}\text { Elemen data ini menggambarkan } \\
\text { deskripsi tekstual dari isi ini sumber } \\
\text { belajar. }\end{array}$ & $\checkmark$ \\
\hline 1.6 & Kata Kunci & $\begin{array}{l}\text { Elemen data ini menggambarkan kata } \\
\text { kunci atau frase yang menggambarkan } \\
\text { pembelajaran sumber daya.Elemen data } \\
\text { tidak boleh digunakan untuk } \\
\text { karakteristik yang dapat digambarkan } \\
\text { oleh elemen data lainnya. }\end{array}$ & 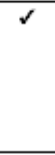 \\
\hline
\end{tabular}

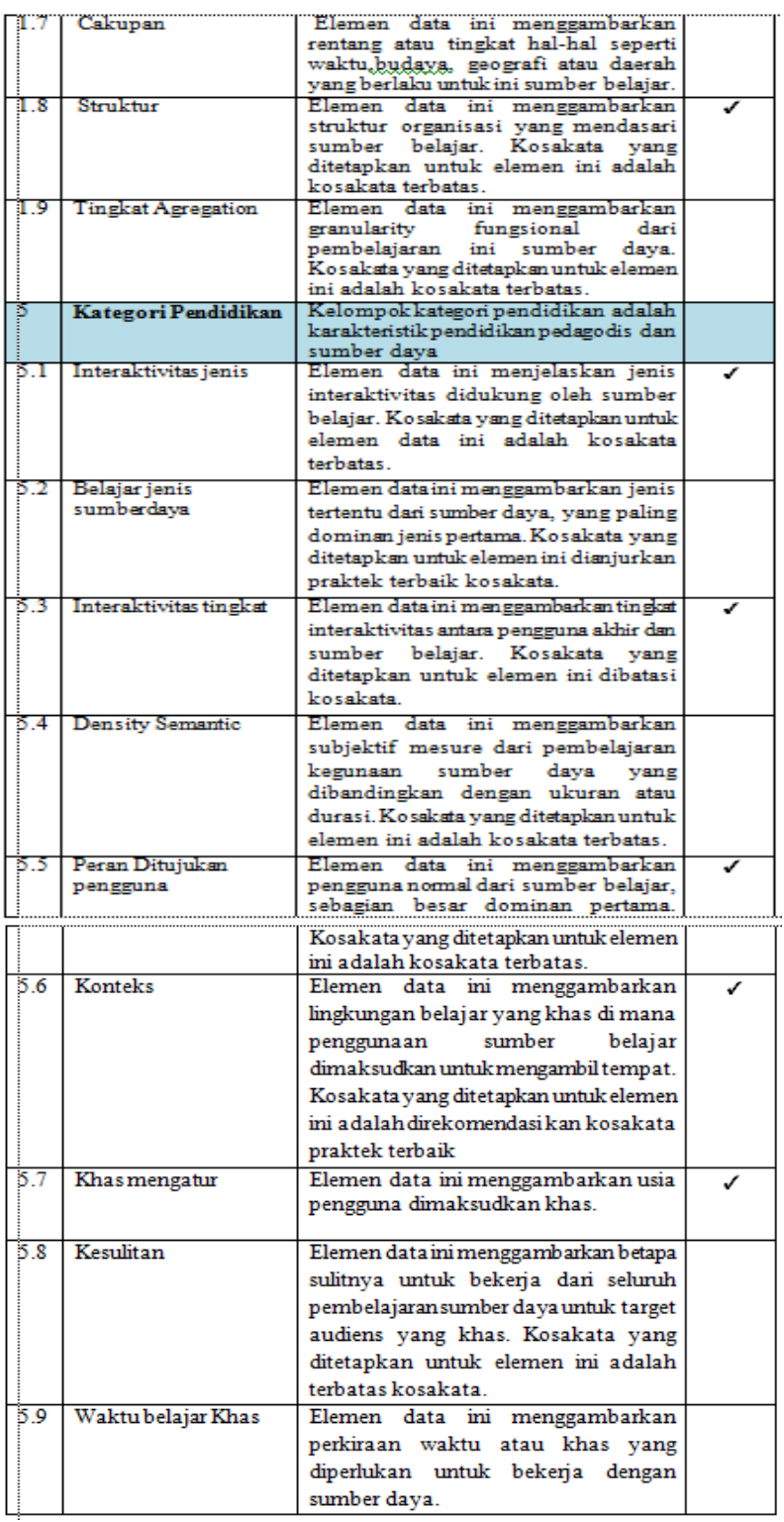

Data yang di dapat dari hasil penelitian ini adalah data kualitatif. Data kualitatif yaitu data yang di peroleh dari analisa berdasarkan aspek-aspek dalam standar SCORM CAM 1.2

Dari tabel yang ada pada gambar 4.1 dapat disimpulkan bahwa:

a. Nr.1 Kategori Umum

Nr.1 Kategori Umum pada standar SCORM merupakan ketentuan dalam proses menggambarkan sumber daya informasi secara keseluruhan. Dari hasil analisa terhadap kategori 
umum ada 7 kategori yang memenuhi deskripsi kategori umum dalam website e-learning FIK.

b. Nr 5 Kategori Pendidikan

Kelompok kategori pendidikan adalah karakteristik pendidikan pedagodis dan sumber daya. Dari hasil analisa terhadap kategori Pendidikan ada 5 kategori yang memenuhi deskripsi kategori pendidikan dalam website $e$-Learning FIK.

Berikut adalah tampilan website $e$-Learning FIK UBL sesuai dengan kategori-kategori umum dan kategori pendidikan dalam standar SCORM CAM.

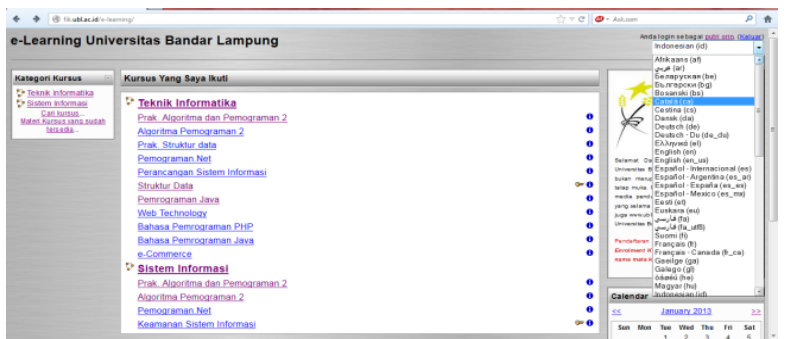

Gambar 4.1 Tampilan Beranda website e-Learning

Dari gambar 4.1 pada tampilan beranda website $e$ Learning diatas terdapat beberapa kategori umum dan kategori pendidikan dalam standar SCORM CAM yaitu:

\section{Pada Kategori Umum}

1. Nr 1.1 Identifier Elemen data ini untuk menggambarkan label global yang unik untuk mengidentifikasi sumber belajar.

2. Nr 1.2 Judul Elemen data ini menggambarkan nama yang diberikan untuk sumber belajar.

3. Nr 1.4 Bahasa Elemen data ini menggambarkan bahasa manusia utama atau bahasa yang digunakan dalam hal sumber belajar untuk berkomunikasi dengan pengguna yang dimaksudkan.

4. Nr 1.4 Bahasa Elemen data ini menggambarkan bahasa manusia utama atau bahasa yang digunakan dalam hal sumber belajar untuk berkomunikasi dengan pengguna yang dimaksudkan.

\section{Pada Kategori Pendidikan}

1. $\mathrm{Nr} 5.1$ Interaktivitas Jenis Elemen data ini menjelaskan jenis interaktivitas didukung oleh sumber belajar

2. Nr 5.6 Konteks Elemen data ini menggambarkan lingkungan belajar yang khas di mana penggunaan sumber belajar dimaksudkan untuk mengambil tempat.

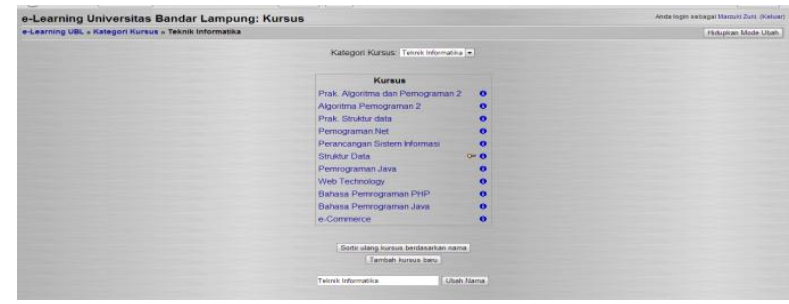

Gambar 4.2 Tampilan kategori Kursus TI website $e$-Learning

Dari gambar 4.2 pada tampilan kategori kursus TI pada website e-Learning terdapat beberapa kategori umum yang memenuhi standar SCORM CAM yaitu :

1. Nr 1.3 Katalog Entri Elemen ini menggambarkan data entri dalam katalog (yaitu sebuah daftar identifikasi sistem) yang ditugaskan untuk sumber belajar. Kategori sub-harus menjelaskan sumber belajar menurut beberapa sistem katalogisasi dikenal sehingga memungkinkan mencari secara eksternal yang terletak sesuai dengan metodologi sistem tertentu.

2. Nr 1.5 Deskripsi Elemen data ini menggambarkan deskripsi tekstual dari isi ini sumber belajar.

3. Nr 1.6 Kata Kunci Elemen data ini menggambarkan kata kunci atau frase yang menggambarkan pembelajaran sumber daya.

4. Nr 1.8 Struktur Elemen data ini menggambarkan struktur organisasi yang mendasari sumber belajar.

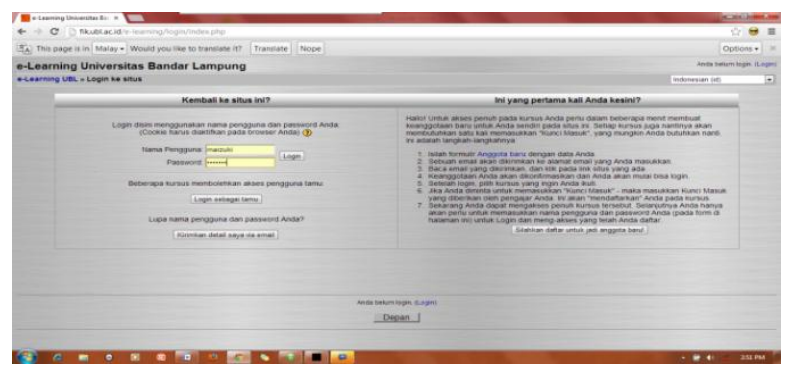

Gambar 4.3 Tampilan Login Dan Pendaftaran pada $e$ Learning FIK UBL

Dari gambar 4.3 pada tampilan login pada e-Learning FIK UBL terdapat beberapa kategori pendidikan yang sesuai dengan standar SCORM CAM yaitu :

1. Nr 5.3 Interaktivitas Tingkat Elemen data ini menggambarkan tingkat interaktivitas antara pengguna akhir dan sumber belajar. Kosakata yang ditetapkan untuk elemen ini dibatasi kosakata.

2. Nr 5.5 Peran Ditujukan Pengguna Elemen data ini menggambarkan pengguna normal dari sumber belajar 
3. $\mathrm{Nr} 5.7$ khas Mengatur Elemen data ini menggambarkan usia pengguna.

\section{KESIMPULAN}

Berdasarkan penelitian secara keseluruhan menghasilkan beberapa temuan penting yang dapat dirumuskan dalam kesimpulan sebagai berikut:

Website e-learning FIK UBL belum memenuhi standar SCORM CAM. Banyak kategori-kategori dan konten dalam design materi yang belum tersedia dalam website e-Learning tersebut sesuai dengan standar SCORM seperti pada kategori umum dan kategori pendidikan yang belum sepenuhnya diterapkan dalam website $e$ Learning FIK UBL.

\section{DAFTAR PUSTAKA}

[1] Effendi, Empy, SE., MBA, dan Hartono Zhuang, ST., MBA. 2008. e-Learning Konsep dan Aplikasi. Yogyakarta: Andi.

[2] Satria Wahono, Romi. 2003. Pengantar e-Learning dan Pengembangannya. http://www.ilmukomputer.com//.

[3] Koran, Jaya Kumar C. 2001. Aplikasi E-learning dalam Pengajaran dan Pembelajaran di SekolahSekolah Malaysia.

[4] Rahardja, B. 2001. Internet untuk Pendidikan. http://budi.insan.co.id/internet-pendidikan.doc.

[5] Sharable Content Object Reference Model (SCORM) version 1.2 : 2001, ADL http://www.adlnet.org//

[6] Jogiyanto H.M., Analisa dan Desain, Andi Offset, Yogyakarta, 1995.

[7] Booch, Grady, Jacobson, Ivan and Rumbaugh, James. (1998). The Unified Modeling Language Reference Manual. United States of America.

[7] Anonymous. 2009 Balanced Scorecard. http://www.balancedscorecard.org//

[8] Turban, E, 1995, Decision Support System and Intelligence System:Fourth Edition, Prentice Hall

[9] Race, W.H., \& Nash S.S. (2010). Moodle 1.9 teaching techniques: Creative ways to build powerful and affective online course. Birmingham: PACKT Publishing.

[10] Herman Wibowo (Penterjemah). 1993. Analisa Laporan Keuangan. Jakarta: PT. Erlangga 